\title{
Cross-border co-authorships in scientific articles and knowledge flows: Implications for investigating an emerging international system of innovation
}

\author{
Leonardo Costa Ribeiro: Inmetro, Rio de Janeiro, Brazil (Postal Address: Avenida Nossa \\ Senhora das Graças 50, Duque de Caxias, Rio de Janeiro, Brazil, CEP 25250-020) \\ Márcia Siqueira Rapini: Cedeplar-UFMG, Belo Horizonte, Brazil (Postal Address: Avenida \\ Antônio Carlos 6627, Belo Horizonte, Minas Gerais, Brazil, CEP 31270-901) \\ Leandro Alves Silva: Cedeplar-UFMG, Belo Horizonte, Brazil (Postal Address: Avenida \\ Antônio Carlos 6627, Belo Horizonte, Minas Gerais, Brazil, CEP 31270-901) \\ Eduardo da Motta e Albuquerque: Cedeplar-UFMG, Belo Horizonte, Brazil (Postal \\ Address: Avenida Antônio Carlos 6627, Belo Horizonte, Minas Gerais, Brazil, CEP 31270- \\ 901) CORRESPONDING AUTHOR: albuquer@cedeplar.ufmg.br
}

\begin{abstract}
This paper tracks knowledge flows through cross-border co-authorships in scientific publications, through a database with 10 million papers published in 2000, 2003, 2006 2009, 2012 and 2015. The data show an increase in international co-authorships from $10.7 \%$ in 2000 to $21.3 \%$ in 2015 . These co-authorships generate a network among the author's institutions that links (international flows) have grown from 545,372 in 2000 to $7,083,075$ in 2015. This network is a free-scale network that has preserved its structure while it grows. This paper explores implications of the size, growth and structure of this network of international collaboration in science for emerging process of formation of an international system of innovation.
\end{abstract}

KEY WORDS: knowledge flows, international co-authorships, science, innovation systems

JEL CLASSIFICATION: O30

\section{RESUMO}

O presente trabalho aborda os fluxos de conhecimento através de co-autorias internacionais em publicações científicas indexadas, através de uma base de dados com 10 milhões de artigos publicados em 2000, 2003, 2006, 2009, 2012 e 2015. Os dados mostram um aumento das co-autorias internacionais de 10,7\% 2000 a $21,3 \%$ em 2015. No entanto, esse crescimento tem propriedades de rede, já que o número de fluxos internacionais passou de 545.372 em 2000 para 7.083.075 em 2015. O crescimento do tamanho, da dimensão e da qualidade desses fluxos científicos fortalece um amplo e variado mosaico de interconexões que pode ser apreendido pelo tamanho da rede de co-autorias internacionais, uma rede que pode estar apoiando a emergência de um sistema global de inovação ainda rudimentar.

PALAVRAS-CHAVE: fluxos de conhecimento, co-autorias internacionais, ciência, sistemas de inovação 


\section{INTRODUCTION}

This paper uncovers the properties of the network of international collaboration in science, using as proxy the international co-authorship in ISI-indexed scientific papers. The data collected and analyzed in this paper show that international collaboration has been growing with a peculiar pattern: it is faster than an exponential growth. This international collaboration forms a network; a free-scale network that has preserved its structure while it grows. This paper explores implications of the size, growth and structure of this network of international collaboration in science for an emerging process of formation of an international system of innovation.

Science might be an important component of the more general growth of international knowledge flows that connect different national systems of innovation. Empirical evidence and theoretical reflection have been accumulating on this growth: a report from OECD summarizes data and evidence on a mosaic of forms that knowledge spills over national boundaries (OECD, 2015, chapter 3).

The literature on national systems of innovation (NSIs) has been aware of the role of international flows since its earlier works (Patel and Pavitt, 1998). More than twenty years ago, Nelson and Rosenberg (1995, pp. 17-18) have highlighted this tension between the international dimension of technology and the national boundaries of innovation systems. Recently, Soete et all (2010, p. 1176) - in a section entitled "from national to international systems of innovation" -, mention that "a feature which has increasingly challenged the notion of NSI is of course the rapid growth in international research and knowledge flows". Soete et al (2010, p. 1176) highlight how "globalization of knowledge flows represents a real challenge for systems of innovation policies".

In previous works we have discussed those different flows (Britto et al, 2013) and investigated flows through patent citations of scientific papers (Ribeiro et al, 2014). This paper focuses just on science - another solid basis for corroding national boundaries between systems of innovation. After all, science can be understood as an international endeavor per se, always avoiding to be restrained by national boundaries (Science, 2017, pp. 694-697)

To analyze those flows through science, this paper organizes statistics of ISIindexed papers and the institutional location of their authors. A database with 10,021,195 papers and documents published in 2000, 2003, 2006, 2009, 2012 and 2015 was prepared. The literature (for example, Nature, 2016b and NSF, 2016, p. 5-102) has documented the presence, spread and growth of international collaboration through international coauthorships, and Table 1 summarizes our data for those well-known phenomena: countries involved in those collaborations were 174 in 2000 and 200 in 2015 and an increase in international co-authorship from $10.7 \%$ in 2000 to $21.3 \%$ in 2015.

Those data, specially those 418,000 papers with international collaboration in 2015, show that a threshold might have been overcome: they equal the total of scientific papers published in 1993, according to data from the National Science Foundation (NSF, 1996, p. 5-31). 
TABLE 1

Articles, total and with international co-authorship, also in percentage of international co-authorship (2000 - 2015)

\begin{tabular}{ccccc}
\hline Year & $\begin{array}{c}\text { Total } \\
\text { Articles }\end{array}$ & $\begin{array}{c}\text { Articles With } \\
\text { Inter Flow }\end{array}$ & $\%$ & $\begin{array}{c}\text { Countries } \\
\text { w/ Inter } \\
\text { Flow }\end{array}$ \\
\hline 2000 & $1,274,329$ & 136,483 & $10.7 \%$ & 174 \\
2003 & $1,360,275$ & 166,672 & $12.3 \%$ & 184 \\
2006 & $1,517,189$ & 197,940 & $13.0 \%$ & 189 \\
2009 & $1,885,092$ & 265,460 & $14.1 \%$ & 190 \\
2012 & $2,019,563$ & 329,190 & $16.3 \%$ & 189 \\
2015 & $1,964,747$ & 418,866 & $21.3 \%$ & 200 \\
\hline \hline
\end{tabular}

SOURCE: Web of Knowledge, authors' elaboration (Database A)

The literature has identified the network created by those international collaborations (Wagner et al, 2005 and 2015). The investigation of this network and its properties organizes this paper. The first section presents our tentative framework of national systems of innovation (NSIs) being transformed by cross-border knowledge flows - scientific flows among them. The second section focuses on global collaboration in science, to rephrase our research question and to put forward the investigation on the network of those collaborations and its properties. The third section presents data and methodology. The fourth section presents a picture of international co-authorship descriptive statistics on countries and S\&E fields. The fifth section presents an analysis of the network of those international co-authorships in science. The final section concludes the paper.

\section{TENTATIVE FRAMEWORK: CROSS-BORDER KNOWLEDGE FLOWS CONNECTING DIFFERENT NATIONAL SYSTEMS OF INNOVATION}

The elaboration on NSIs organizes the role of different institutions (firms, universities, research institutes, etc.) for technological progress. This approach focused mainly in national spaces, but since the beginning put forward the role of international relationships and related tensions created by the transnational nature of technology and the international propensity of science (see, as an example, Nelson and Rosenberg, 1995, pp. 17-18). Even the literature that tried to question impressionist visions about the rhythm of internationalization of technology (Patel, 1995) illustrates international connections and flows.

The transnational corporations are one of the drivers of the tension in relation to national borders of innovation systems: they organize flows that connect firms from different countries. There is a huge and growing literature on the internationalization of R\&D.

Dunning and Lundan (2009) focus on "patterns of the internationalization of the knowledge-creating and knowledge-sourcing activities of MNEs" (p. 13). They collect evidence on "three main trends": 1) "the internationalization of the innovative activities of MNEs has lagged behind that of their productive activities"; 2) "foreign affiliates have gained substantially more autonomy and now play a far more important role in the 
knowledge-creating activities of the MNE as a whole", furthermore, Dunning and Lundan stress that those foreign affiliates "link the internal network of the MNE with national or regional innovation systems within which they are embedded"; 3) given new players in the global economy, "the innovative activities of MNEs have become more geographically dispersed than has been the case before" (p. 13). In the conclusion, Dunning and Lundan (2009, pp. 27-28) suggest a correlation between the growth of internationalization of "knowledge-creating activities of MNEs" "over the past three decades" (p. 27) and an evolution towards "more autonomy to foreign affiliates" (p. 28).

Cantwell (2013) integrates changes in internal knowledge flows within the MNEs (that depend upon ICT revolution) and their new relationships with external knowledge flows with changes that have been blurring the frontiers between science and technology. Those changes may signal the "changing nature of knowledge creation" (p. 4), with implications leading to a more complex set of knowledge flows, both within MNEs and between them and other firms and other institutions. There is a key transformation: "the shift from the MNC as an institution for technology transfer between established activities frequently organized along miniature replica lines in different locations, and towards the MNC as a developer of international networks for technology creation, which combine formerly unconnected streams of innovation" (p. 18). Correlated to those changes, there would be the emergence of open innovation (p. 9). The interaction between MNEs and institutions related to open innovation may introduce a more direct link between global firms and scientific infrastructure, worldwide. According to OECD (2008, p. 9), MNEs "increasingly line up with start ups, spinoffs and public R\&D system".

Laurens et al (2015) address two questions: is there a "growing trend in the internationalization of technology creation" and does "the 'home-base-augmenting' strategy still dominate? In the conclusion, Laurens et al (p. 773) raise the issue of a plateau in the internationalization rate, "beyond which, as suggested by Gammeltoft, organizational issues become too complex to be efficiently managed". Laurens et al $(2015$, p. 773$)$ caution against "generalizations previously made from case study analyses and by quantitative analyses done one decade ago".

Those references and a large literature on innovation focusing in international flows reviewed by Britto et al (2013, pp. 79-83) support a suggestion of a tentative framework in which multinationals, their R\&D activities and the scientific institutions connect different national systems of innovation (see Britto et al, 2013, p. 80, Figure 1). TNCs are key organizers of several of those international flows (Fuchs, 2014; Cantwell, 2009), but they are not alone: universities and research institutes have their own international connections, and those connections transform the interactions between universities and firms.

Those flows that connect different NSIs have received systematic and continuous attention by researchers and institutions, as the literature shows. OECD (2015, chapter 3 ) is useful to summarize the role of broader flows such as "mobility of highly skilled individuals", "scientists on the move", "excellence in scientific collaboration", "research across borders", "inventions across borders", "international markets for knowledge", "open innovation" and "collaboration on innovation".

Those references put forward two issues, one theoretical and another empirical.

Theoretically, the size and scope of all those cross-border flows put forward a question: where are we in the transition from national systems of innovation to an emerging global system of innovation? Of course it is too early to talk about a global system of innovation, but we are in a point where the tension between the national dimension of 
systems of innovation and the international proclivity of science and technology has increased strongly.

Empirically, those broad flows and connections might suggest that our tentative framework simplifies and underestimates the scale and scope of international knowledge flows.

2. LITERATURE REVIEW: GLOBAL COLLABORATION IN SCIENCE What is the specificity of science as a connector of different NSIs?

The literature uses international co-authorships in scientific papers as proxy for international collaboration (Glänzel and Schubert, 2005; Wagner et al, 2015, pp. 4-5). However, Katz and Martin (1997) argue that collaboration is broader than co-authorship an issue that makes sense both at national and international level.

Knowledge flows in science are increasingly acknowledged in the literature as an important issue. Beyond the OECD's (2015, chapter 3) references to connections in knowledge, other benchmark publications stress the importance of those flows. NSB (2016, pp. 5/105-5/109), for instance, evaluates carefully those international connections, presenting general data (Figure 5-26, p. 5/103), co-authorship by country (Figure 5-28, p. 5/106), disaggregating international collaboration by field (Figure 5-27, p. 5/101). NSB (2016, p. 5/110) also analysis the international flows through cross-national citations, another "evidence that S\&E research is increasingly international in scope". Adams (2013, p. 557) suggests that "we are entering a fourth age of research, driven by international collaborations between elite research groups".

Academically, there is a long list of important works dealing with internationalization of science (brief reviews are presented by Wagner et al, 2005, pp. 1609-1610; Freeman, 2015, p. 18; Wagner et al, 2015, p. 2).

Freeman (2010, pp. 394-399) presents a good reference for the specific role of international co-authorship among the "globalization of S\&E knowledge": it is one of the "five fingers of S\&E knowledge", together with "expansion of mass higher education worldwide", "growth in number of international students", "immigration", "nonimmigration trips: academic visitors, conferences" and "greater international co-authorship and co-patenting". Later, Freeman articulates those fingers to conjecture that "[g]iven that collaborations generally arise from personal connections, it is hard to imagine internationally coauthored research expanding absent researcher mobility" (2017, p. 696).

This increase in international co-authorship may be rooted in two related phenomena. First, collaboration and teamwork in science are necessary, given the growth of accumulated knowledge, the increased specialization and complexity of science teamwork is a general trend in science (Jones, 2011, pp. 112, 124, 128). OECD (2016, p. 28) provides a link to the second phenomenon, related to other shifts in science: "[t]he production of scientific research is progressively shifting from individuals to groups, from single to multiple institutions, and from national to international level". Freeman (2015, p. 18) lists reasons for international cooperation in science: "the spread of scientific workers and R\&D across the world", "growing number of S\&E PhDs in developing countries", government and R\&D spending in developing countries and policies in Europe for international cooperation, the "increased presence of China in scientific research", and "the location of scientific equipment and materials" (CERN, huge telescopes, specificity of geological and climate data). 
Wagner $(2005,2015)$ goes a step further uncovering not only the growth of those international co-authorships, but also the network properties of international co-authorship in science (2005) and investigating the "dynamics of the global network" (2015, p. 8).

Investigating six S\&E fields, 65 journals and 19,147 papers, Wagner et al (2005, pp. 1612-1614) found a "very high degree of connectedness among authors in the network" (p. 1612), suggesting a "power law form", but one that "cannot be fitted into a single powerlaw dependence" (p. 1613). The results suggest a "scale free distribution of co-authorships" (p. 1614). Later, Wagner et al (2015) use a broader database (with 787,001 relevant documents in 2011 and 193,216 international co-authorships) to investigate "global networks of science", analyzing their formation and stabilization, to finally collect evidence to support their suggestion that international collaboration "represent a self-organizing phenomena" (2015, p. 8). The growth of the global network of research "is an emerging organization added (and possibly superseding) the national model". More than the stabilization and self-organization of those scientific networks, Wagner et al $(2015$, p. 12) suggest that they impact other levels of innovation systems: "[t]he global network is arguably now a more stable system that serves as a source of vitality and direction to R\&D at all lower levels". As a evidence of a transition to a more global system, Wagner et al (2015, p. 12) evaluate that those changes create new governance problems, as the "global cooperation networks", a "dynamic system", operate "orthogonally to national systems".

The dialogue with the works and findings of Wagner et al $(2005,2015)$ may organize the next sections. First, we would like to investigate the network properties of a broader and less constrained database to answer one question (2005, p. 1613): is the network of international co-authorships free-scale? Second, we would like to investigate the "dynamics of evolving networks" (2005, p. 1612).

For this dialogue, there are three issues for this paper: 1) to prepare a database large enough to limit the constraints in the analysis - 10 million ISI-indexed documents, for 6 different years between 2000 and 2015 ; 2) to investigate the properties of those international co-authorships networks: are they free-scale?; 3 ) to evaluate the long term behavior of those networks.

\section{DATA AND METHODOLOGY}

Our starting point is a database generated through information provided by Thomson Reuters' WebOfScience (www.webofknowledge.com). From this source - WebOfScience - on papers published from 2000, 2003, 2006, 2009, 2012 and 2015, totaled more than 10 million articles, according to Table 1 . The basic search in the WebOfScience involved: a) publications that included articles, meeting abstracts, book reviews etc; b) publications from all fields; ${ }^{1}$ c) sources such as journals, conference proceedings, etc (our database included information from 105,840 different sources ${ }^{2}$ - this is an important difference vis-à-via Nature Index, that includes 68 top journals); d) the data for our database involved the following topics on each document: title, author(s),

\footnotetext{
${ }^{1}$ WebOfScience has 252 different S\&E disciplines. To process those data by more aggregated areas we applied Braun et all (1995a, 1995b) suggestion - as close as possible: $170 \mathrm{~S} \& \mathrm{E}$ disciplines were aggregated into 27 fields (see Table A2, Appendix for this list). In this aggregation $82 \mathrm{~S} \& \mathrm{E}$ disciplines were not used, since they are related to human and social sciences and have no correspondence in the aggregation strategy of Braun et al (1995a, 1995b).

${ }^{2}$ We do as Wagner et al $(2005$, p. 1611) that uses all types of documents in their analysis.
} 
institutional location(s) (address: institution, country), science and engineering field, information on funding of the paper.

\section{AN OVERALL PICTURE: INTERNATIONAL CO-AUTORSHIP IN SCIENTIFIC PRODUCTION}

This section organizes a preliminary presentation of our databases, providing basic statistics about them. Three topics are described for this preliminary mapping of international co-authorship: countries, S\&E disciplines and types of interactions.

\subsection{COUNTRIES}

There are 206 countries in our database for 2015. Table 2 shows the scientific production ranked by leading countries, showing the total production and the international collaboration (co-authorship) in 2015. USA, China, England, German and Japan are the leaders in the scientific production of 2015 , representing $47.9 \%$ of total production. These same countries, with the exception of Japan, also lead the international co-authorship articles. These five countries in 2015 represented $18.78 \%$ of total international collaborative scientific production, being less concentrated than the total production. So, an important observation is that collaborative scientific production is more spread around the Global Knowledge System.

TABLE 2

Ranking of leading countries according to total of articles, and the percentage of their international co-authorships (2015)

\begin{tabular}{rcrr}
\multicolumn{1}{r}{ Rank } & Country & \multicolumn{1}{c}{ Articles } & $\%$ Inter \\
\hline 1 & USA & 415421 & $15,8 \%$ \\
2 & PEOPLES R CHINA & 278613 & $17,9 \%$ \\
3 & ENGLAND & 91111 & $28,4 \%$ \\
4 & GERMANY & 87890 & $29,6 \%$ \\
5 & JAPAN & 72330 & $13,3 \%$ \\
6 & INDIA & 59732 & $12,7 \%$ \\
7 & ITALY & 59668 & $27,8 \%$ \\
8 & CANADA & 55496 & $26,3 \%$ \\
9 & FRANCE & 55149 & $31,0 \%$ \\
10 & SOUTH KOREA & 53446 & $15,3 \%$ \\
11 & AUSTRALIA & 51590 & $27,2 \%$ \\
12 & SPAIN & 48845 & $28,3 \%$ \\
13 & BRAZIL & 38649 & $20,7 \%$ \\
14 & RUSSIA & 31422 & $16,7 \%$ \\
15 & NETHERLANDS & 29840 & $35,1 \%$ \\
16 & TURKEY & 28721 & $10,3 \%$ \\
17 & IRAN & 27443 & $16,5 \%$ \\
18 & POLAND & 24110 & $17,1 \%$ \\
19 & TAIWAN & 23836 & $15,2 \%$ \\
20 & SWITZERLAND & 19151 & $42,9 \%$
\end{tabular}

SOURCE: WebOfScience, authors' elaboration (Database A)

Since we have data since 2000 , to be further evaluated in other works, we may follow China's evolution: in 2000 China was at the 8th position (12th in international flow), and in 2012, she was ranked at the 2nd position in both. 
The distribution of countries according to their percentage of international coauthorship is summarized in Graph 1 - a histogram that shows the number of countries in each range of percentage of international co-authorship (5\% is the range chosen).

Three peaks may be shown in Graph 1.

The first, around 30\%, (20 countries) - is composed basically by countries that their national systems of innovation are not completely formed - countries that are in "regime of interaction" 2 according to Chaves et al (2017): examples are Mexico (25.11\%), Philippines (27.49\%), South Africa (28.08\%) and Thailand (29.90\%). In this peak there are also countries in the "regime of interaction" 3: Canada (26.27\%), England (28.42\%) and Germany (29.58\%) - not so small "regime 3" countries.

\section{GRAPH 1}

HISTOGRAM - distribution of 206 countries according to the percentage of their articles with international co-autorship (2015)

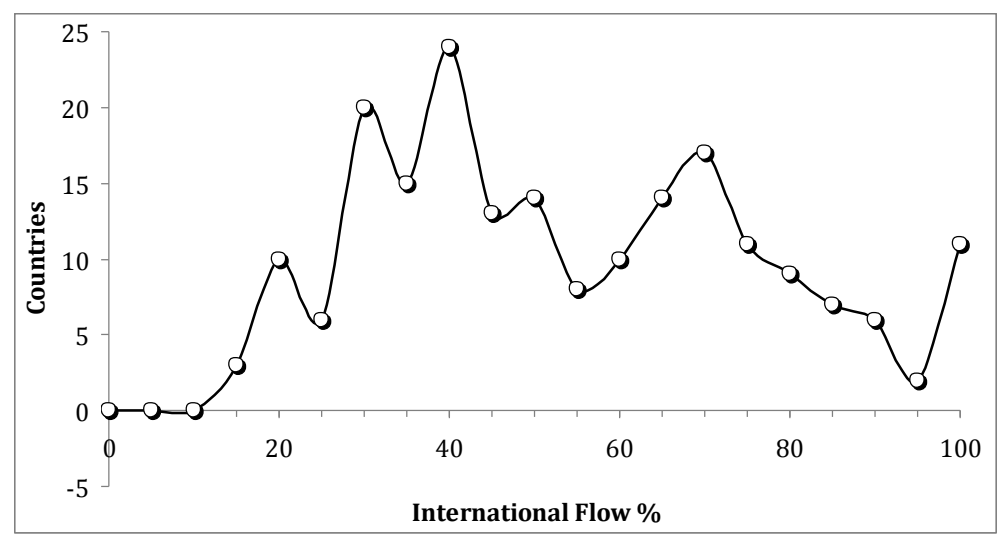

SOURCE: WebOfScience, authors' elaboration (Database A)

The second peak, around $40 \%$, is predominantly from small countries located in the $3^{\text {rd }}$ "regime of interaction": Sweden $(36.38 \%)$, Netherlands $(35.12 \%)$ are examples of this set of countries. There are also smaller countries from "regime of interaction" 2: Chile $(39.70 \%)$.

Finally, the third peak (around 70\%, with 21 countries) is composed only by countries located at "regime of interaction" 1: Uganda, Ecuador, and Kenya. It seems that beyond $60 \%$ of international co-authorship, there are only countries located at "regime of interaction" 1 or countries in a worst position than that - countries without USPTO applications. $^{3}$

Those correlations are to be further evaluated, but, a preliminary analysis may suggest some patterns. First, least developed countries, countries with rudiments of national systems of innovation, depend strongly of international cooperation to start (Kruss et al, 2015, p. 15), therefore their high levels of international co-authorship. Second, dynamic innovation systems of small countries are more internationalized than the average. Thirdly, larger countries with strong national scientific base are proportionally less internationalized

\footnotetext{
${ }^{3}$ Exceptions: Qatar ("regime of interaction" 2, with $63.47 \%$ of international co-authorship); and very small European countries - Andorra, Liechtenstein, Monaco, San Marino.
} 
than the average, although they are leaders in absolute terms - see the positions of USA and China in Table 4.

\subsection{WebOfScience S\&E DISCIPLINES}

There are 252 WebOfScience S\&E disciplines in our database. Table 3 shows the scientific production ranked by leading S\&E disciplines, displaying the total production and the percentage of international collaboration (co-authorship) in 2015.

Table 3 presents the leading S\&E disciplines as organized by the WebOfScience, their total and their percentage of international co-authorship. As in the distribution for countries, the S\&E disciplines with more articles are not the disciplines with more international co-authorship. The two leading S\&E disciplines in scientific production (Chemistry and Biochemistry) are not the leading disciplines in percentage of international co-authorship (Astronomy and Physics, particles). However, if in the case of countries the highest levels in the percentage of international co-authorship were correlated to least developed countries, in the case of S\&E disciplines other logic might be operating international nature of S\&E fields might be an explanation.

TABLE 3

Leading Science and Engineering disciplines and international co-autorship (2015)

\begin{tabular}{lcc}
\hline \multicolumn{1}{c}{ Web of SCIenCe S\&E discipline } & Articles & $\begin{array}{c}\% \text { Inter } \\
\text { Flow }\end{array}$ \\
\hline CHEMISTRY, MULTIDISCIPLINARY & 64.525 & 21,27 \\
BIOCHEMISTRY E MOLECULAR BIOLOGY & 64.342 & 23,16 \\
MULTIDISCIPLINARY SCIENCES & 62.161 & 29,88 \\
ONCOLOGY & 56.323 & 18,73 \\
CHEMISTRY, PHYSICAL & 45.922 & 26,59 \\
ENGINEERING, ELECTRICAL E ELECTRONIC & 45.203 & 20,87 \\
CLINICAL NEUROLOGY & 40.966 & 18,45 \\
CARDIAC E CARDIOVASCULAR SYSTEMS & 36.588 & 17,65 \\
MEDICINE, GENERAL E INTERNAL & 34.394 & 14,05 \\
GASTROENTEROLOGY E HEPATOLOGY & 32.063 & 13,31 \\
MATERIALS SCIENCE, MULTIDISCIPLINARY & 31.277 & 21,33 \\
ENVIRONMENTAL SCIENCES & 28.788 & 27,92 \\
NEUROSCIENCES & 23.633 & 25,46 \\
PHARMACOLOGY E PHARMACY & 23.286 & 19,27 \\
PUBLIC, ENVIRONMENTAL E OCCUPATIONAI & 23.069 & 25,3 \\
COMPUTER SCIENCE, ARTIFICIAL INTELLIGEN & 22.884 & 24,36 \\
BIOTECHNOLOGY E APPLIED MICROBIOLOG' & 22.878 & 23,52 \\
MATHEMATICS, APPLIED & 22.369 & 27,89 \\
PLANT SCIENCES & 20.861 & 28,77 \\
PHYSICS, MULTIDISCIPLINARY & 20.532 & 25,38 \\
ENDOCRINOLOGY E METABOLISM & 20.481 & 21,32 \\
SURGERY & 19.652 & 10,76 \\
IMMUNOLOGY & 19.149 & 24,39 \\
ASTRONOMY E ASTROPHYSICS & 17.744 & 51,44
\end{tabular}

SOURCE: WebOfScience, authors' elaboration (Database A)

The distribution of S\&E disciplines according to their percentage of international co-authorship is summarized in Graph 2 - a histogram that shows the number of S\&E disciplines in each range of percentage of international co-authorship $(2.5 \%$ is the range chosen).

Graph 2 shows three peaks. 
The first peak, around $2.5 \%$ of international co-authorship, involves $21 \mathrm{~S} \& \mathrm{E}$ disciplines - all are not related to the S\&E fields organized by Braun (1995a, 1995b). In fact, until 5\% of international co-authorship the disciplines are not of those S\&E fields.

The second peak, around $22.5 \%$ (close to the international average of $21.3 \%$ ), involves $33 \mathrm{~S} \& \mathrm{E}$ disciplines, that together with neighbor ranges $15 \%$ to $30 \%$ there are 180 S\&E fields (the leading fields in Table 6 are in this broad region).

The third peak, around 37.5\%, involves 9 S\&E disciplines, highly internationalized - examples are Geochemistry, Parasitology, and Meteorology.

\section{GRAPH 2}

HISTOGRAM - distribution of 252 S\&E disciplines according to the percentage of their articles with international co-autorship (2015)

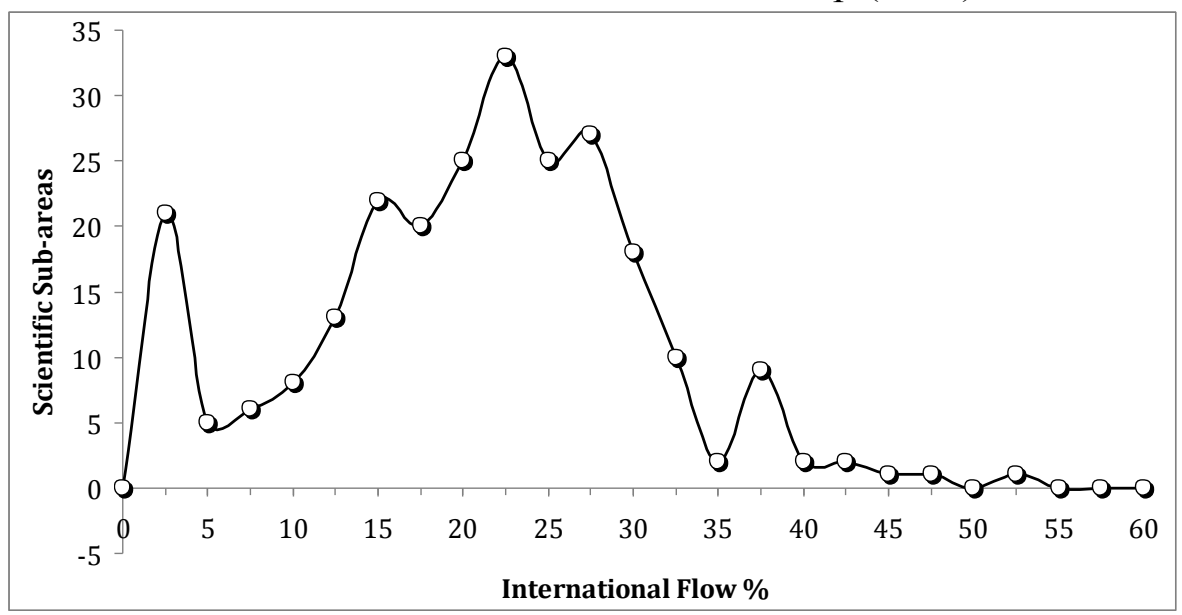

SOURCE: WebOfScience, authors' elaboration (Database A)

\section{A PRELIMINARY ANALYSIS OF THE NETWORK OF INTERNATIONAL CO- AUTHORSHIP}

In 2015 international co-authorship was $21.3 \%$ of total scientific production, as big as the global scientific production in 1993. However, those data might underestimate the importance of those international co-authorship flows, as articles with international coauthorship are produced by international research efforts that may involve more than two different institutions. Therefore, one article with international co-authorship may involve more than one international flow linking two institutions in two different countries - one article may generate various international flows. International flows may grow more than international co-authorship.

Table 4 shows those important data.

Table 4 shows that, although international co-authorship has grown 3.06 times between 2000 and 2015 - reaching 418,866 articles with international co-authorship -, the international flows between institutional authors have grown 12.99 times - reaching $7,083,075$ cross-border pairs, or individual international flows, in 2015 . Those very simple calculations based on data from Table 4 are informative enough to suggest important 
network properties of those scientific international collaborations, already identified by Wagner et al $(2005,2015){ }^{4}$

TABLE 4

Size of the network of international co-authorships, according to number of pairs (links) by interaction types (2000 - 2015)

International Co-authorship Pairs

\begin{tabular}{crrrrrr} 
Interaction & \multicolumn{7}{c}{} & $\mathbf{2 0 0 9}$ & $\mathbf{2 0 1 2}$ & $\mathbf{2 0 1 5}$ \\
\cline { 2 - 7 } Type & $\mathbf{2 0 0 0}$ & $\mathbf{2 0 0 3}$ & $\mathbf{2 0 0 6}$ & $\mathbf{2 0 0 9}$ & 7257669 & 7019906 \\
RI-RI & 530424 & 566816 & 968723 & 1613794 & 7250 \\
RI-Firm & 14154 & 17983 & 20717 & 31668 & 56129 & 60940 \\
Firm-Firm & 794 & 856 & 1085 & 1324 & 3309 & 2229 \\
\hline \hline Total & 545372 & 585655 & 990525 & 1646786 & 7317107 & 7083075 \\
& SOURCE: WebOfScience, authors' elaboration (Database A)
\end{tabular}

Those international flows are dominated by research institutions. The first line shows the academic interactions between Research Institutes (RI-RI). The flows among them were 530,424 in 2000 and exponentially grew to 7,0199,966 pairs in 2015. The second line of Table 7 shows interactions between Research Institutes and Firms, which grew 4.31 times between 2000 and 2015, from 14,154 pairs in 2000 to 60,940 in 2015. The third line shows Firms-Firms pairs that grew only 2.81 times, from 794 to 2,229 pairs.

Table 4 puts forward the dimension of the phenomenon that this paper investigates: given the networks properties displayed by our analysis, international co-authorships involve 7,083,075 cross-border pairs or individual international flows. A phenomenon that goes far beyond what the figures for articles with international co-authorships may show. Just to stress how important are those data from Table 6 for our tentative framework presented in Figure 1, the reader could imagine a World Map with 7,083,075 arrows connecting universities and firms across planet Earth.

\subsection{COUNTRIES AS NODES OF THE NETWORK}

Table 5 shows 2.31 million links. Since one paper may have more than one coauthor institution, their country will count only once in this paper.

The ranking of countries according to connections in the international coauthorships network is different from conventional rankings (total papers and papers with international co-authorship). The USA keep the leading position in those three rankings (see Tables 4 and 6), while China is at the second position in Table 4 but in the 4 th position in Table 6.

The distribution of connections per country is also very uneven. The United States of America have connections with 202 other countries, China with other 173 countries, Netherlands with 179 countries and Brazil with 171 countries. Least developed countries are connected with fewer countries: Mozambique with 101 countries, Bolivia with 78 countries, Liberia with 42 countries, and Angola with 32 countries.

\footnotetext{
${ }^{4}$ Wagner et al (2015, p. 6) analyze data from 1990 to 2011, and find a growth in the "number of coauthor relationships (links)" that is "disproportionately large compared to the growth in the number of addresses".
} 
This network connects all 206 countries. As discussed in sub-section 4.1, least developed countries or countries with rudiments of an innovation system begin their science and technology activities with strong support from more developed countries.

\section{TABLE 5}

NETWORK ANALYSIS: Ranking of leading countries as nodes according to total of links in their international co-authorships, and the number of countries that those links connect (2015)

\begin{tabular}{lrr}
\hline Node & Links & Countries \\
\hline USA & 273628 & 202 \\
ENGLAND & 150343 & 193 \\
GERMANY & 139864 & 185 \\
PEOPLES R CHINA & 108608 & 173 \\
FRANCE & 107849 & 188 \\
ITALY & 91429 & 187 \\
SPAIN & 78042 & 178 \\
CANADA & 76588 & 182 \\
AUSTRALIA & 73851 & 186 \\
NETHERLANDS & 69379 & 179 \\
SWITZERLAND & 61305 & 181 \\
JAPAN & 50182 & 171 \\
SWEDEN & 48931 & 173 \\
BELGIUM & 43943 & 174 \\
BRAZIL & 37141 & 171 \\
DENMARK & 36190 & 162 \\
AUSTRIA & 34259 & 158 \\
SCOTLAND & 32850 & 165 \\
SOUTH KOREA & 32695 & 147 \\
RUSSIA & 32656 & 153 \\
POLAND & 32382 & 136 \\
INDIA & 30708 & 167 \\
NORWAY & 25934 & 158 \\
FINLAND & 25291 & 147 \\
PORTUGAL & 24833 & 156 \\
CZECH REPUBLIC & 24631 & 143 \\
GREECE & 23737 & 140 \\
TAIWAN & 21663 & 144 \\
TURKEY & 20962 & 148 \\
SOUTH AFRICA & 20851 & 171 \\
& &
\end{tabular}

SOURCE: WebOfScience, authors' elaboration (Database A)

\subsection{INSTITUTIONS AS NODES OF THE NETWORK}

Table 6 shows each institution as a node of the network and the total connections in each node. Since each of the 7.08 million links shown in Table 6 has two participants, the total of column Links in Table 8 is 14.16 million. The most connected institutions and their links are displayed in Table 8. 
Table 6 shows universities leading the ranking of connections ( 8 first positions). The logic of connections is different than the logic of total of articles and of the logic of total international co-authorships: our data show that the Chinese Academy of Sciences leads both rankings, but is in the 13th position in the ranking of connections (Table 8).

TABLE 6

NETWORK ANALYSIS:

Leading institutions (network nodes) according to the number of links with international co-authors

(2015)

\begin{tabular}{ll}
\hline \multicolumn{2}{c}{ International Co-authorship Links per Node - 2015 } \\
\hline Node & Links \\
\hline UNIV OXFORD (ENGLAND) & 54813 \\
UNIV CAMBRIDGE (ENGLAND) & 50481 \\
UNIV TORONTO (CANADA) & 47843 \\
HARVARD UNIV (USA) & 47100 \\
UCL (ENGLAND) & 45773 \\
UNIV COPENHAGEN (DENMARK) & 45395 \\
CHARLES UNIV PRAGUE (CZECH REPUBLIC) & 45074 \\
UNIV ATHENS (GREECE) & 45073 \\
CNRS (FRANCE) & 44920 \\
UNIV BOLOGNA (ITALY) & 44447 \\
UNIV EDINBURGH (SCOTLAND) & 44087 \\
CENTRE ETUDES RECHERCHE (SWITZERLAN & 42351 \\
CHINESE ACAD SCI (PEOPLES R CHINA) & 41786 \\
IST NAZL FIS NUCL (ITALY) & 41767 \\
UNIV LONDON IMPERIAL COLL SCI TECHNC & 41477 \\
UNIV BELGRADE (SERBIA) & 40466 \\
UNIV MELBOURNE (AUSTRALIA) & 40418 \\
HEIDELBERG UNIV (GERMANY) & 40299 \\
UNIV MALAYA (MALAYSIA) & 40103 \\
MOSCOW MV LOMONOSOV STATE UNIV( & 40099 \\
UNIV PISA (ITALY) & 40025 \\
UNIV PARIS 11 (FRANCE) & 39977 \\
OHIO STATE UNIV (USA) & 39735 \\
UNIV MANCHESTER (ENGLAND) & 39203 \\
MIT (USA) & 39166 \\
UNIV NAPLES FEDERICO II (ITALY) & 38489 \\
UNIV GENOA (ITALY) & 38433 \\
UNIV SYDNEY (AUSTRALIA) & 38248 \\
UNIV AUTONOMA MADRID (SPAIN) & 38085 \\
UNIV GLASGOW (SCOTLAND) & 37886 \\
UNIV BRITISH COLUMBIA (CANADA) & 37257 \\
LUND UNIV (SWEDEN) & 37198 \\
&
\end{tabular}

SOURCE: WebOfScience, authors' elaboration (Database A) 
Location of most connected firms would be around the 545th position (Novartis, with more than 5,000 connections), and the 7,200th position (Robert Bosch, with 80 connections). ${ }^{5}$

Graph 3 presents, for 2015, the distribution of the 163,410 institutions according to the number of connections that they have presented - a histogram that shows the number of institutions (frequency) according to the number of connections that they have. There are 50,889 institutions with one link, and one institution with 54,813 links. The data for 2000 are also plotted in Graph 5, to investigate the inter-temporal stability of this network.

\section{GRAPH 3}

HISTOGRAM: distribution of institutions with international co-authorships according to the number of connections

(2015)

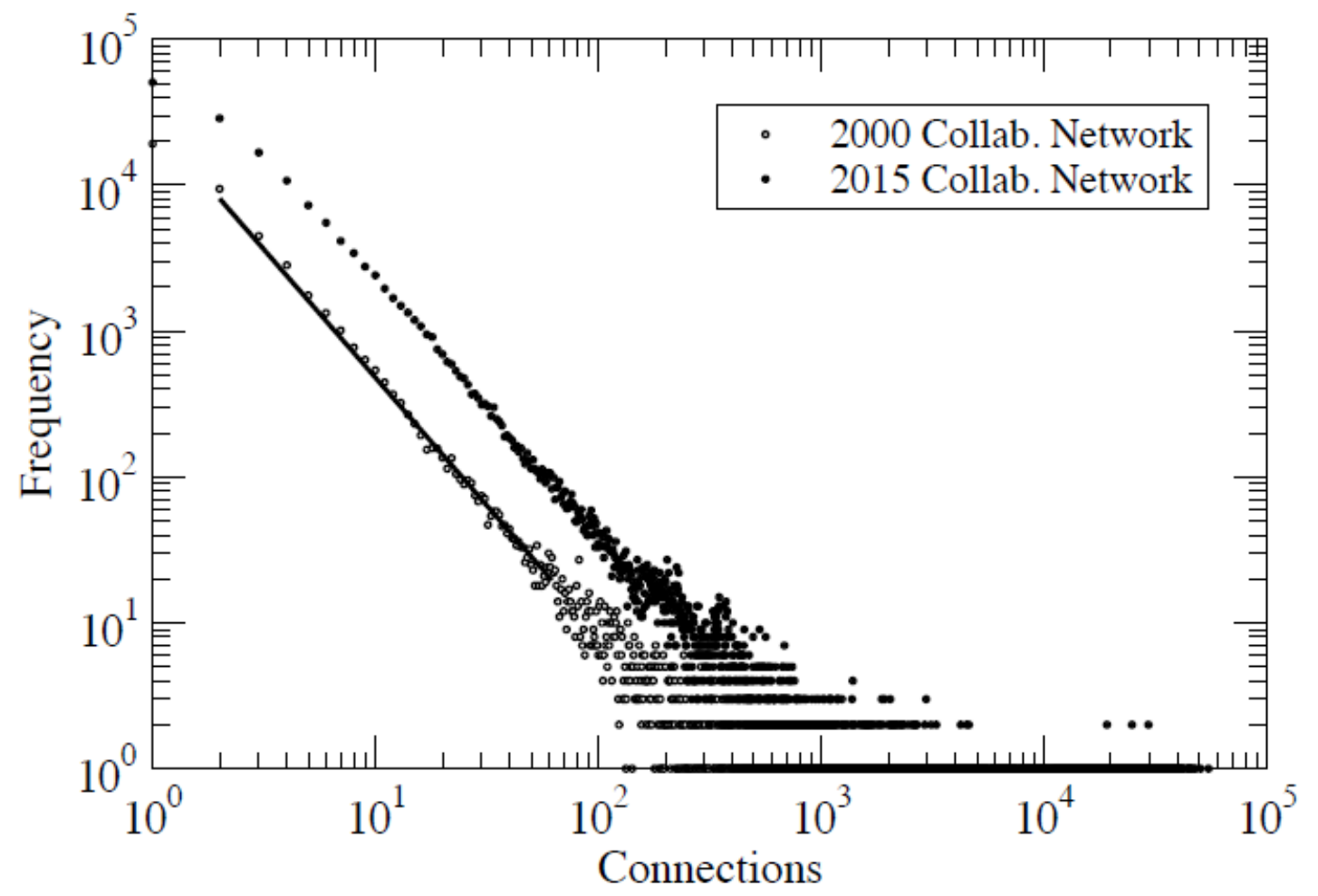

SOURCE: WebOfScience, authors' elaboration (Database A)

The power law (the straight line in a $\log \mathrm{x} \log$ scale) behavior of the distribution of connections (links) indicates that the international co-authorship network is a free-scale one, both in 2000 and 2015. So, it shows a small number of nodes with a very high connection (called hubs) and a huge number of nodes with not so many connections. The

\footnotetext{
${ }^{5}$ A comparison with patent citation of ISI-indexed paper as a knowledge flow for firms and co-authorship of scientific papers: in 2009, the leading firm in patents with citation of ISI-indexed paper was Microsoft, with 333 patents - or links (Ribeiro et al, 2014, Table 2, p. 72). Microsoft has more than 650 connections (links) through international co-authorship. The leading firm in connections through international co-authorship in our preliminary calculations is Novartis, with more than 5,000 links.
} 
hubs represent the institutions that attract and concentrate a large number of international collaborations translated into co-authorship in papers. Their behavior influences the global features of the network (they might define the mainly research interests). In general, this sort of network is generated by systems that show a self-organization property, thus the power law in Graph 3 may indicate that the system that generated it is in a self-organization state.

The identification in the network of international co-authored scientific papers of properties of a self-organized system, already highlighted by Wagner $(2005,2015)$, is a finding that supports an evaluation of the contribution of science and its flows for the emergence of a global system of innovation.

The final question is about the behavior of the network over time: does it change? Table 7 presents an analysis of the distribution of the network for 2000, 2003, 2006, 2009, 2012 and 2015, calculating the exponents of the power law distribution.

TABLE 7

POWER LAW DISTRIBUTION OF THE NETWORK OF INTERNATIONAL COLLABORATION IN SCIENCE (2000-2015)

\begin{tabular}{rrrrrr}
\hline Year & $\begin{array}{c}\text { Papers w/ } \\
\text { Inter. Collab. }\end{array}$ & $\begin{array}{c}\text { Institutions } \\
\text { (network nodes) }\end{array}$ & $\begin{array}{c}\text { Inter. Collab. } \\
\text { (network links) }\end{array}$ & $\begin{array}{c}\text { Links per } \\
\text { Node }\end{array}$ & $\begin{array}{c}\text { Power Law } \\
\text { Exponent }\end{array}$ \\
\hline 2000 & 136,483 & 48,373 & 545,372 & 11 & 1.73 \\
2003 & 166,672 & 61,290 & 585,655 & 10 & 1.78 \\
2006 & 197,940 & 75,747 & 990,525 & 13 & 1.72 \\
2009 & 265,460 & 101,829 & $1,646,786$ & 16 & 1.72 \\
2012 & 329,190 & 129,067 & $7,317,107$ & 57 & 1.72 \\
2015 & 418,866 & 163,044 & $7,083,075$ & 43 & 1.70 \\
\hline \hline
\end{tabular}

SOURCE: WebOfScience, authors' elaboration (Database A)

The network structure can be univocally identified analyzing its connection distribution behavior. The power law relation found for all those years (from 2000 until $2015)$ in the connection distribution implies that the analyzed network of international collaboration among institutions is a free-scale one.

Wagner at all (2005, p. 1613) analyzed the international collaboration in six S\&E fields using countries as nodes (in the six Graphs displayed their X-axis are never greater than 100) and found indications that the network is also a free-scale. However, they found a significant deviation from the power-law likely due to the number of countries that limited their analysis to two orders of magnitude (100 countries). As there are much more available institutions than countries, we can extend the analysis to more orders of magnitude when the institutions network is analyzed. As Graph 5 shows we found a very low deviation from the power-law and the analyses reach five orders of magnitude (163,044 institutions in 2015).

As the international collaboration network is free-scale, it should follow the generation rule of this kind of network. It has a small number of nodes (compared to the size of the network) called hubs that have a large number of connections, alongside a large number of nodes with a small number of connections. In order to build this type of network, a small, fully connected sub-graph (e.g. 5 nodes connected to each other) is first 
established. Then new nodes are added one by one to the initial core, connecting them to a fixed number of other nodes. Each node connects to others with a probability proportional to their number of connections. Therefore, a node that due to statistical fluctuations receives more connections than the others during the initial stages will get increasingly more connections, becoming a hub. Similarly, poorly connected nodes tend to continue with a low level of connections (Barabasi et al, 1999; Albert et al, 2000).

Therefore, the hubs play a special role on this kind of network and their behavior dominates the behavior of the network as a whole. This means that when a researcher is seeking a collaborator, they will seek someone who is already highly connected. It may indicate high quality research and reputation. As Table 7 shows, there is an increase in the number of nodes (institutions) in the network, and as those new institutions join the network, they connect to leading institutions, reinforcing existing hubs. These few institutions that attract this myriad of connections may influence somehow the research developed by their collaborators, probably defining research topics of interest. In other words, there is a hierarchy between those institutions.

\section{CONCLUDING REMARKS: INTERNATIONALIZATION OF SCIENTIFIC PRODUCTION AND ITS CONTRIBUTION TO THE EMERGENCE OF AN GSI}

The literature review in sections 1 and 2 has shown how well known is the process of expansion of scientific production worldwide and the correlated growth of international collaboration, measured by statistics of international co-authorships.

Our database and our methodology presented in section 3 supported two contributions of this paper.

On the one hand, new data for old knowledge: a systematization of descriptive statistics using our data, to show the spread and consistency of this international expansion of scientific collaboration - by country, S\&E fields (section 4) and economic sectors (section 5) - a methodology to connect different databases was necessary for those data.

On the other hand: new data for new questions put forward by previous research (Wagner, 2005), more specifically, the nature (free-scale network?) and the dynamics of this evolving network.

It is important to highlight a contribution of the network built from the scientific production to the process of emergence of rudiments of a global system of innovation. Science and the knowledge flows are important components in our tentative framework (section 1), not only quantitatively - size of the flows -, but also qualitatively - the nature of those flows and the properties of their network. Our investigation found the free-scale nature of the network of international co-authorship in science - the size of our database gives us orders of magnitude large enough to evaluate the power law and to conclude that it is free-scale. This means that this network has a hierarchical structure.

Furthermore, with data for different years between 2000 and 2015, our database contributed to another issue: the dynamics of this evolving network. Table 4 shows the more than exponential growth of this network between 2000 and 2015. Our investigation shows that there is this exponential growth, but the structure of the network is preserved the network is free-scale in all years evaluated - see Table 7.

What do those combined findings mean?

First, there are the implications of the growth of scientific production and international scientific collaboration. As over time technological progress is increasingly more dependent upon science, every country needs to be plugged in the international 
scientific networks as a precondition for their development. Science in non-developed countries may be an antenna to guide even very initial steps of technological progress. Scientific flows through international co-authorships are more spread than other flows. This is an evidence captured by a comparison with a previous research: in a previous article we investigated another set of knowledge flows: flows through patent citations of ISI-Indexed papers, as clues for ways that firms (with their patents) used knowledge generated in research institutions. In that investigation, with data for 2009 , we found 70,000 links - a patent on one side, a paper in the other side, predominantly a connection between a citing firm and a cited university (Ribeiro et al, 2014, p. 77). A rough quantitative comparison juxtaposes 418,866 international co-authorships and 70,000 cross-border patent citations of scientific papers. Cross-border flows from international co-authorships in articles are broader than flows from patent citations of ISI-indexed papers: the USA, for instance, in 2015 have connections with 202 countries through international co-authorships (see Table 5 ), while have only 81 countries connected through patent citations in 2009 (Ribeiro et al, 2014, p. 77). Therefore, we may conjecture that knowledge flows through science broader than those through technology, may be an important starting point for lessdeveloped countries - an important contribution of this global scientific expansion.

Second, the shape of the network: being a free-scale network means that there is hierarchy in it. The international scientific flows may be eroding national borders, but the global system in sight is hierarchical. Freeman (2010, p. 394) discusses challenges put forward by the globalization of scientific knowledge. Probably, the hierarchical shape, a very stable one during such an exponential growth, might be an important challenge to international public policy to devise ways, on the one hand, to preserve the growth of worldwide scientific knowledge and international collaboration and, on the other hand, to think about growth that may be more well distributed. This may be very relevant because science, vis-à-vis technology, appears to be a more equalizing force in this initial process of formation of an international system of innovation.

Finally, the role of MNEs in those networks must be stressed. MNEs are part of other technological flows that link different NSIs, but they are part of network of science, acting also as drivers of internationalization of scientific activities. The involvement of MNEs, seen as "a knowledge network", in the scientific activities globally distributed may be part of what Dunning and Lundan (2009, p. 239) identify as a "structural transformation" that pushes those global firms to become engines "to gather dispersed knowledge". Evidences on the structural similarities of the whole network of scientific international collaboration and the network involving MNEs may be a sign of how those global firms behave as the other institutions of the network.

\section{REFERENCES}

ADAMS, J. (2013) The fourth age of research. Nature, v. 497, 30 May 2013, n. xxx, pp. 557-559.

ANDERSON, P. W. 1972. More is different: broken symmetry and the nature of the hierarchical structure. Science, 177(4047), 393-396. doi:

10.1126/science.177.4047.393 
BRAUN, T.; GLANZEL, W.; GRUPP., H. (1995a) The Weight of 50 Nations in 27 Science Areas, 1989-1993 (Part I: All fields combined, Mathematics, Engineering, Chemistry and Physics). Scientometrics, v. 33, n. 3, pp. 263-293.

BRAUN, T.; GLANZEL, W.; GRUPP., H. (1995b) The Weight of 50 Nations in 27 Science Areas, 1989-1993 (Part II: Life Sciences). Scientometrics, v. 34, n. 2, pp. $207-$ 237.

BRITTO, G.; CAMARGO, O. S.; KRUSS, G.; ALBUQUERQUE, E. M. (2013) Global interactions between firms and universities: global innovation networks as first steps towards a Global Innovation System. Innovation and Development, v. 3, n. 1, pp. 7188 .

CAMPBELL, W. C. (2015) Ivermectin: a reflection on simplicity. Nobel Lecture. Stockolm: Nobel Foundation (https://www.nobelprize.org/nobel_prizes/medicine/laureates/2015/campbelllecture.pdf).

CANTWELL, J. (2009) Innovation and information technology in the MNE. In: RUGMAN, A. M. (ed.), The Oxford Handbook of International Business. Oxford University Press: Oxford, Second Edition, pp. 417-446.

CANTWELL, J. (2013) Blurred boundaries between firms, and new boundaries within (large multinational) firms: the impact of decentralized networks for innovation. Seoul Journal of Economics, v. 26, n. 1, pp. 1-32.

CHAVES, C. V., RIBEIRO, L. C.; SANTOS, U. P.; ALBUQUERQUE, E. (2017) Sistemas de inovação e mudanças na divisão centro-periferia: notas sobre uma metodologia para identificar trajetórias de países a partir de estatísticas de ciência e tecnologia. Belo Horizonte: Cedeplar-UFMG (Unpublished manuscript).

CHEN, C.J., HUANG, Y.F., LIN, B.W. (2012) How firms innovate through R\&D internationalisation? An S-curve hypothesis. Research Policy 41, 1544-1554.

DUNNING, J.; LUNDAN, S. (2008) Multinational enterprises and the global economy. Cheltenham: Edward Elgar (Second edition).

DUNNING, J.H., LUNDAN, S.M., (2009) The internationalisation of corporate R\&D: a review of the evidence and some policy implications for home countries. Review of Policy Research, 26, 13-33.

EUROPEAN COMMISSION (2008) EUROSTAT: Methodologies and Workingpapers, NACE Rev. 2: Statistical classification of economic activities in the European Community, Luxembourg: Office for Official Publications of the European Communities.

ERNST, D. (2006) Innovation offshoring: Asia's emerging role in Global Innovation Networks. East-West Center: Honolulu.

FUCHS, M. (2014) Worldwide knowledge? Global firms, local labour and the region. Surrey: Ashgate.

GEORGHIOU, L. (1998) Global cooperation in research. Research Policy, v. 27, n. 6, pp. 611-626. 
GILliES, J.; CAILliAU, R. (2000) How the web was born: the story of the World Wide Web. Oxford/New York: Oxford University Press.

GLÄNZEL, W.; SCHUBERT, A. (2005). Domesticity and internationality in coauthorship, references and citations. Scientometrics, v. 65, n. 3, pp. 323-342.

GUELLEC, D.; POTTERIE, B. (2004) Measuring internationalization of the generation of technology: an approach based on patent data. In: MOED, H.; GLÄNZEL, W.;

$\mathrm{SCHMOCH}, \mathrm{U}$. (eds). Handbook of quantitative science and technology research: the use of publication and patent statistics in studies of S\&T systems. Dordrecht: Kluwer Academic Publishers, pp. 645-662.

HICKS, D. (1995) Published papers, tacit competencies, and corporate management of public/private character of knowledge. Industrial and Corporate Change, v. 4, n. 2, pp. 401-424.

HYMER, S. (1976) The International Operations of National Firms: A study of direct foreign investiment. Cambridge: MIT Press.

JAFFE, A.; TRAJTENBERG, M.; FOGARTY, M. (2000) Knowledge Spillovers and Patent Citations: Evidence from a Survey of Inventors. American Economir Review, v. 90, n. 2, pp. 215-218.

KERR, S. P.; KERR, W.; OZDEN, C.; PARSONS, C. (2016) Global talent flows. Journal of Economic Perspectives, v. 30, n. 4, pp. 83-106.

KRUSS, G.; LEE, K.; SUZIGAN, W.; ALBUQUERQUE, E. (2015) Introduction. In: ALBUQUERQUE, E.; SUZIGAN, W.; KRUSS, G.; LEE, K. Developing National Systems of Innovation: University-Industry interactions in the Global South.

Cheltenham/Ottawa: Edward Elgar/IDRC, pp. 1-28 (available at http://www.elgaronline.com/view/9781784711092.00007.xml)

LAURENS, P.; Le BAS, C.; SCHOEN, A.; VILLARD, L.; LARÉDO, P. (2015) The rate and motives of the internationalization of large firm R\&D (1994-2005): towards a turning point? Research Policy, v. 44, n. 3, pp. 765-776.

LEYDESDORFF, L.; WAGNER, C. (2008) International collaboration in science and the formation of core group. Informetrics, v. 2, n. 4, pp. 317-325.

LINDEN, G.; KRAEMER, K. L.; DENDRICK, J. (2007), Who captures value in a Global Innovation System? The case of Apple`s iPod. Personal Computer Industry Center/University of California: Irvine Irvine.

LOS, B.; TIMMER, M.; de VRIES, G. J. (2015) How global are global value chains? A new approach to measure international fragmentation. Journal of Regional Science, $\mathrm{v}$. 55, n. 1, pp. 66-92.

NATIONAL SCIENCE BOARD. 1996. Science and Engineering Indicators 1996. Arlington, VA: National Science Foundation

NATIONAL SCIENCE BOARD. 2016. Science and Engineering Indicators 2016. Arlington, VA: National Science Foundation

NATURE (2016a) Nature Index (http://www.natureindex.com/) (accessed 19 november 2016). 
NATURE (2016b) International research collaborations on the rise. Nature Index (http://www.natureindex.com/news-blog/international-research-collaborations-on-therise - accessed 19 november 2016).

NELSON, R.; ROSENBERG, N. (1995). Introduction. In: NELSON, R. (ed). National innovation systems: a comparative analysis. New York, Oxford: Oxford University.

OECD (1998), L'internationalisation de la R\&D industrielle: structures et tendances. OECD: Paris.

OECD (2008), The internationalization of business R\&D: evidence, impacts and implications. OECD: Paris.

OECD (2013) Interconnected economies: benefiting from global value chains. Paris: OECD.

OECD (2015) OECD Science, Technology and Industry Scoreboard 2015: Innovation for growth and society, OECD Publishing, Paris. http://dx.doi.org/10.1787/sti_scoreboard2015-en

OECD and SCImago Research Group (CSIC) (2016) Compendium of Bibliometric Science Indicators. OECD, Paris. Accessed from http://oe.cd/scientometrics.

PATEL, P. (2011) Location of innovative activities of EU large firms. SPRU Electronic Working Paper Number 190, downloaded on 17 May 2015 from http://www.sussex.ac.uk/spru/documents/sewp190.pdf

PATEL, P.; PAVITT, K. (1998), National systems of innovation under strain: the internationalization of corporate R\&D. SPRU: Brighton.

RIBEIRO, L. C.; RUIZ, R. M.; BERNARDES, A. T.; ALBUQUERQUE, E. M. (2010) Matrices of science and technology interactions and patterns of structured growth: implications for development. Scientometrics, v. 83, pp. 55-75.

RIBEIRO, L. C. ; KRUSS, G. ; BRITTO, G. ; RUIZ, R. M. ; BERNARDES, A. T. ; ALBUQUERQUE, E. M. (2014) A methodology for unveiling global innovation networks: patent citations as clues to cross border knowledge flows. Scientometrics, v. 101, pp. 61-83.

ROSENBERG, N. (1990). Why do firms do basic research (with their money)? Research Policy, v. 19, pp.165-174.

SCHLAGBERGER, E. M.; BORNMANN, L.; BAUER, J. (2016) At what institutions did Nobel laureates do their prizewinning work? An analysis of biographical information on Nobel laureates from 1994 to 2014. Scientometrics, v. 109, n. 2, pp. 723-767.

SILVA, L. (2014) Tensões e conexões: um estudo sobre multinacionais e sistemas nacionais de inovação. Belo Horizonte: Cedeplar-UFMG (Tese de Doutorado).

SOETE, L.; VERSPAGEN, B.; WEEL, B. (2010) Systems of innovation. In: HALL, B.; ROSENBERG, N. (eds) Handbook of the economics of innovation. Volume II. Amsterdam: North Holland.

TEECE, D. (2006) Reflections on the Hymer thesis and the multinational enterprise. International Business Review, v. 15, n. 2, pp. 124-139. 
TIMMER, M. P.; ERUMBAN, A.; LOS, B.; STEHRER, R.; de VRIES, G. (2014) Slicing up global value chains. Journal of Economic Perspectives, v. 28, n. 2, pp. 99-118.

UNCTAD (2005), World Investment Report 2005 - Transnational corporations and the internationalization of R\&D. United Nations Conference on Trade and Development: Geneva.

UNCTAD (2006), World Investment Report 2006 - FDI from developing and transition economies: implications for development. United Nations Conference on Trade and Development: Geneva.

UNCTAD (2011), World Investment Report 2011 - Non-equity modes of international production and development. United Nations Conference on Trade and Development: Geneva.

UNCTAD. (2011) World Investment Report 2011 - Non-equity modes of international production and development. Geneva: United Nations Conference on Trade and Development.

UNCTAD. (2013) World Investment Report 2013 - Global value chains: investment and trade for development. Geneva: United Nations Conference on Trade and Development.

WAGNER, C.; LEYDESDORFF, L. (2005) Network structure, self-organization, and the growth of international collaboration in science. Research Policy, v. 34, n. 10, pp. 1608-1618.

WAGNER, C.; PARK, H. W.; LEYDESDORFF, L. (2015) The continuing growth of global cooperation networks in research: a conundrum for national governments. PLOS one, July 21, 2015 